\title{
Evaluation of Early Maladaptive Schemas in Female Fibromyalgia Patients
}

\author{
Kadın Fibromyalji Hastalarında Erken Dönem Uyumsuz Şemaların Değerlendirilmesi
}

${ }^{1}$ Fatih Yigman, ${ }^{2}$ Zeynep Aykin Yigman, ${ }^{3}$ Damla Cankurtaran

Department of Psychiatry, Ufuk University Faculty of Medicine, Ankara, Turkey

${ }^{2}$ Ankara Polatlı Duatepe State Hospital, Physical Medicine and Rehabilitation Clinic, Ankara, Turkey

${ }^{3}$ Department of Physical Medicine and Rehabilitation, SBU Dıșkapı Yildirim Beyazit Training and Research Hospital, Ankara, Turkey

\section{Correspondence:}

Fatih YIGMAN

Department of Psychiatry, Ufuk

University Faculty of Medicine,

Ankara, Turkey

e-mail: dr.yigman@gmail.com

\section{Abstract}

Fibromyalgia is a condition characterized by widespread musculoskeletal pain and tenderness without an underlying organic cause. Relationships with psychological factors and personality traits have been reported in many studies. In this study, we aimed to examine the relationship between early maladaptive schemas (EMS) and fibromyalgia severity from the perspective of schema theory. For the study, 73 patients with fibromyalgia who applied to the Physical Medicine and Rehabilitation outpatient clinic and were diagnosed with fibromyalgia were included. In addition, 78 healthy control patients (without additional psychiatric disease and chronic pain) were included. A sociodemographic data form, Young Schema Questionnaire - Short Form 3 (YSQ -SF3) and Fibromyalgia Impact Questionnaire (FIQ) self-report scale was administered to the participants. We found significantly higher scores on emotional deprivation, failure to achieve, dependence/ incompetence, vulnerability to harm, enmeshment, subjugation, self-sacrifice, and pessimism/negativity schemas in the patient group. We also found positive correlations with FIQ scores, emotional deprivation, and vulnerability to harm schemas. Finally, we found that age was a positive predictor on FIQ scores. After controlling for age, we found that emotional deprivation and vulnerability to harm schemas predicted FIQ scores. Fibromyalgia is a disease of unknown etiology. Psychological factors should be considered in the holistic treatment approach. In this sense, schema theory-oriented perspective can contribute to the treatment process.

Keywords: Fibromyalgia; psychological factors; chronic pain; psychology

\section{Özet}

Fibromyalji, altta yatan organic bir neden olmaksızın, yaygın kas iskelet sistemi ağrısı ve hassasiyeti ile karakterize bir tablodur. Psikolojik faktörler ve kisilik özellikleri ile iliskileri birçok calıșmada bildirilmistir. Bu çalışmada sema teorisi perspektifinden erken dnem uyumsuz şemalar (EMS) ile fibromyalji şiddeti arasındaki ilişkiyi incelemeyi amaçladık. Çalışma için Fiziksel Tıp ve Rehabilitasyon polikliniğine başvuran ve fibromyalji tanısı konulan 73 fibromyalji tanılı hasta dahil edilmiştir. Ek olarak 78 sağlıklı kontrol (ek psikiyatrik hastalığı olmayan ve kronik ağrısı olmayan) hasta dahil edilmiștir. Katılımcılara sosyodemografik veri formu, Young Sema Ölçeği - Kısa Form 3 (YSQ -SF3) ve Fibromyalji Etki Anketi (FIQ) öz bildirim ölçeği olarak uygulanmıştır. Hasta grubunda duygusal yoksunluk, başarısızlık, bağımlılık, dayanıksızlık, iç içelik, boyun eğicilik, karamsarlık şemalarında anlamlı olarak yüksek puanlar saptadık. Ayrıca FIQ puanları ile, duygusal yoksunluk ve dayanıksızlık şemaları ile pozitif korelasyonlar saptadık. Son olarak FIQ skorları üzerinde yaşın pozitif yordayıcılı̆̆ını saptadık. Yas kontrol edildikten sonra ise FIQ skorlarını duygusal yoksunluk ve dayanıksızlık semalarının öngördüğünü saptadık. Fibromyalji, etiyolojisi net olarak belirlenemeyen bir hastalıktır. Bütüncül tedavi yaklaşımında psikolojik faktörler ele alınmalıdır. Bu anlamda şema teorisi yönelimli bakış açısı, tedavi sürecine katkı sağlayabilir.

Anahtar Kelimeler: Fibromyalji; psikolojik faktörler; kronik ağrı; psikoloji 


\section{Introduction}

The typical feature of fibromyalgia is the absence of an underlying organic cause and clinical diagnosis. It is characterized by widespread musculoskeletal pain and tenderness (1). Psychological symptoms such as fatigue, sleep disorders, anxiety, and depression are frequently observed in patients, and their relationship with personality traits has been frequently emphasized (2). On the other hand, it can be said that fibromyalgia is not adequately understood by health professionals (3). The main goal in the treatment of fibromyalgia is to reduce the severity of symptoms (4). Knowing more about the psychological factors identified in the disease process can guide potential intervention targets. The effect of early negative childhood experiences on fibromyalgia has been reported in some studies before (5). It has been shown that childhood maltreatment is associated with fibromyalgia complaints in adulthood (6). In addition, previous studies have reported the importance of childhood experiences concerning pain $(7,8)$. Witnessing physical abuse, emotional abuse, and violence in childhood predicts pain disorders in adulthood (9). According to a meta-analysis, children who have experienced abuse or neglect during childhood are at higher risk of experiencing chronic pain in adulthood (10).

Early maladaptive schemas (EMS) according to schema theory; develop during childhood and adolescence. Early maladaptive schemas develop from childhood and form repetitive patterns throughout life. They often arise as a result of hurtful experiences with parents and play a role in the way you relate to the world. According to schema theory, failure to meet basic needs in childhood plays a role in the development of schemas. Some of these needs are secure attachment, autonomy, acceptance, and self-control. They cause lifelong repetitive patterns (11). In this respect, it can be said that schemas are personality-like models (12). The schemas are found to be more or less severe in all people and their severity may change over time (13). According to schema theory, there are 18 basic schemas; emotional deprivation, defectiveness / shame, mistrust / abuse, abandonment / instability, social isolation / alienation, failure to achieve, self-sacrifice, dependence / incompetence, entitlement, unrelenting standards, vulnerability to harm, enmeshment, subjugation, emotional inhibition, insufficient self-control, pessimism /negativity, approval /admiration-seeking, and self-punitiveness.

Previous studies draw attention to the relationships between schemas and pain disorders $(14,15)$, somatization disorders (16), and migraine (17). However, as far as we know, there is only one study evaluating the relationship of EMS in fibromyalgia patients. In this study, we aimed to determine EMS relationships in fibromyalgia patients. Based on previous data between early adverse experiences and other pain disorders, we suggest that EMS will be higher in patients with a diagnosis of fibromyalgia.

\section{Material and Methods}

\section{Participants and procedure}

The study was organized as quantitative, cross-sectional. The patient group for the study consisted of patients who applied to Ankara Polatl Duatepe State Hospital Physical Medicine and Rehabilitation Polyclinic and were diagnosed with fibromyalgia. Fibromyalgia is more common in female patients. In order to exclude the effects of the gender factor, only female patients were included in the study. As the control group, female hospital staff without any additional psychiatric or chronic painrelated disease were included. Inclusion criteria were determined as being older than 18 years, female gender, volunteering to participate in the study, and being literate. Exclusion criteria were psychotic disorder, mental retardation, addiction diagnoses, neuromuscular disease, and a history of malignancy. A total of 83 patients and 81 healthy controls participated in the study, data from 7 people due to random marking and 6 people due to missing marking were not included in the analysis. In this way, the study was completed with 151 people. For the study, the sociodemographic data form prepared by the researchers, the Young 
Schema Inventory - Short Form 3 (YSQSF3), and the Fibromyalgia Impact Questionnaire (FIQ) in addition to the patient group were applied. Patients who were thought to be clinically diagnosed with depression and anxiety were referred to the psychiatry outpatient clinic after the evaluation.

\section{Statement of Ethics}

Ethics committee approval was obtained from Ankara City Hospital No. 1 Clinical Research Ethics Committee with the number E1-201438 on 06.01.2021. All participants were given an informed consent form about the study. In addition, the Helsinki Declaration rules were complied with for this study.

\section{Scales}

Sociodemographic data form: It is a form created by the research team. It consists of questions such as age, years of education, and additional diseases.

Fibromyalgia Impact Questionnaire (FIQ): It is a Likert-type scale consisting of ten questions. It is a self-report scale and the total score is scored between 0-100 (18). High scores indicate higher fibromyalgia complaints. The Turkish validity and reliability of the scale were established (19).

Young Schema Inventory - Short Form 3 (YSQ-SF3): The scale consists of 90 items and evaluates 18 schemas (20). Higher scores indicate that this schema is more severe. Turkish validity and reliability studies have been conducted for this Likert-type scale (21).

\section{Data analysis}

Data were evaluated with IBM SPSS 15.0 for Windows Assessment Version (Statistical Package Program for the Social Sciences). Age, years of education, and EMS scores between the patient and control groups were evaluated with an independent two-sample ttest. The relationships between EMS and FIQ in the patient group were examined with the Pearson correlation paper. Finally, the predictiveness of the relationships between FIQ and EMS was evaluated by hierarchical regression analysis. In terms of significance, $\mathrm{p}<.05$ was considered significant in all analyzes.

\section{Results}

There were 73 patients and 78 control female participants. The age of the patient group was $42.15 \pm 8.46$ and the control group was 40.95 \pm 5.76 , and there was no significant difference between the groups $(p=.313)$. In terms of education year, it was determined as $15.21 \pm$ 3.07 in the patient group and $17.36 \pm 4.37$ in the control group, and there was a significant difference $(\mathrm{p}=.001)$.

When the patient and control groups were compared, significantly higher scores were found in emotional deprivation, failure to achieve, dependence /incompetence, vulnerability to harm, enmeshment, subjugation, self-sacrifice, and pessimism /negativity schemas (Table-1).

Table-1. Comparison of EMS between the patient and control group

\begin{tabular}{llll}
\hline EMS $($ mean \pm SD $)$ & Hasta $(\mathbf{n}=\mathbf{7 3})$ & Kontrol $(\mathbf{n}=\mathbf{7 8})$ & $\mathbf{p}$ \\
EMD & $10.89( \pm 5.60)$ & $8.46( \pm 3.94)$ & $.003^{*}$ \\
ABAN & $11.34( \pm 4.20)$ & $10.92( \pm 2.83)$ & .477 \\
MIST & $11.11( \pm 4.97)$ & $11.63( \pm 3.61)$ & .467 \\
SOCI & $11.02( \pm 4.84)$ & $10.49( \pm 3.30)$ & .399 \\
DEF & $7.48( \pm 2.42)$ & $7.47( \pm 2.63)$ & .990 \\
FAIL & $10.63( \pm 5.08)$ & $9.20( \pm 3.02)$ & $.040^{*}$ \\
DEP & $10.55( \pm 3.96)$ & $9.26( \pm) 2.16$ & $.015^{*}$ \\
VUL & $14.77( \pm 4.56)$ & $13.37( \pm 2.35)$ & $.021^{*}$ \\
ENM & $12.23( \pm 5.61)$ & $10.31( \pm 2.99)$ & $.010^{*}$ \\
SUB & $11.29( \pm 5.57)$ & $9.63( \pm 3.03)$ & $.012^{*}$ \\
SS & $21.00( \pm 5.15)$ & $19.10( \pm 3.76)$ & $.011^{*}$ \\
EMI & $9.59( \pm 3.76)$ & $10.22( \pm 3.54)$ & .291 \\
USTN & $15.81( \pm 4.75)$ & $15.88( \pm 3.94)$ & .91 \\
ENT & $11.52( \pm 5.11)$ & $12.43( \pm 3.93)$ & .222 \\
\hline
\end{tabular}




\begin{tabular}{llll}
\hline ISC & $12.60( \pm 5.50)$ & $12.74( \pm 3.22)$ & .849 \\
APPS & $15.92( \pm 5.50)$ & $14.51( \pm 3.81)$ & .072 \\
PESS & $14.40( \pm 3.89)$ & $12.61( \pm 3.75)$ & $.005^{*}$ \\
SPUN & $11.66( \pm 4.63)$ & $12.68( \pm 2.50)$ & .073 \\
\hline
\end{tabular}

SD: standard deviation, EMS: Early maladaptive schemas, EMD: Emotional Deprivation, ABAN: Abandonment / Instability, MIST: Mistrust/Abuse, SOCI: Social Isolation / Alienation, DEF: Defectiveness /Shame, FAIL: Failure to Achieve, DEP: Dependence /Incompetence, VUL: Vulnerability to Harm, ENM: Enmeshment, SUB: Subjugation, SS: Self-Sacrifice, EMI: Emotional Inhibition, USTN: Unrelenting Standards, ENT: Entitlement, ISC: Insufficient Self-Control, APPS: Approval /Admiration-Seeking, PESS: Pessimisim /Negativity, SPUN: Self-Punitiveness, *:p<0.05, independent samples t-test

In the second stage, Pearson correlation was applied between FIQ and EMS in the patient group. Accordingly, there were positive correlations between FIQ scores and emotional deprivation $(\mathrm{p}=$.254) and vulnerability to harm $(p=.333)$, and negative correlations between subjugation $(p=-.267)$ and self-punitiveness $(\mathrm{p}=-.363)$. detected (Table-2).

Table-2. Pearson correlations between FIQ and EMS

\begin{tabular}{|c|c|c|c|c|c|c|}
\hline \multirow[b]{2}{*}{ FIQ } & & FIQ & EMD & VUL & SUB & SPUN \\
\hline & $r$ & 1 &, $254^{*}$ &, $333^{* *}$ &,$- 267^{*}$ &,$- 363^{* *}$ \\
\hline \multirow[b]{2}{*}{ EMD } & $\mathrm{p}$ & &, 030 &, 004 & ,023 & ,002 \\
\hline & $\mathrm{r}$ &, $254^{*}$ & 1 & 017 &, $183^{*}$ & ,056 \\
\hline \multirow{3}{*}{ VUL } & $\mathrm{p}$ &, 030 & &, 834 & ,025 & ,497 \\
\hline & $r$ &, $333^{* *}$ &, 017 & 1 & ,023 &,- 086 \\
\hline & $\mathrm{p}$ & ,004 &, 834 & & ,777 & ,293 \\
\hline \multirow[t]{2}{*}{ SUB } & $r$ &,$- 267^{*}$ &, $183^{*}$ &, 023 & 1 &, $230^{* *}$ \\
\hline & $\mathrm{p}$ &, 023 &, 025 & ,777 & &, 004 \\
\hline \multirow[t]{2}{*}{ SPUN } & $r$ &,$- 363^{* *}$ & ,056 &,- 086 &, $230^{* *}$ & 1 \\
\hline & $\mathrm{p}$ & ,002 & ,497 & ,293 & ,004 & \\
\hline
\end{tabular}

Finally, we applied a two-step regression model to determine the predictors of FIQ scores. In the first stage, we found that age was a positive predictor of the effect $(\beta=.232$, $\mathrm{p}<0.05)$. In the second stage, after controlling for age, EMS was included in the model. Emotional deprivation $(\beta=.514, \mathrm{p}<0.05)$ and vulnerability to harm $(\beta=.529, \mathrm{p}<0.05)$ charts significantly predicted FIQ scores (Table-3).

Table-3. Hierarchical regression analysis to identify predictors of FIQ scores

\begin{tabular}{|c|c|c|c|c|c|}
\hline FIQ & $\begin{array}{l}\text { Adjusted R } \\
\text { Square }\end{array}$ & B & SE & $B$ & $95 \% \mathrm{CI}(\mathrm{LL} / \mathrm{UL})$ \\
\hline Step 1 & .040 & & & & \\
\hline Yaş & & .276 & .137 & $.232 *$ & $(.002 / .550)$ \\
\hline Step 2 & .353 & & & & \\
\hline EMD & & .924 & .264 & $.514 *$ & $(.394 / 1.455)$ \\
\hline VUL & & 1.168 & .429 & $.529 *$ & $(.309 / 2.028)$ \\
\hline
\end{tabular}

SE: Standardized Estimated, CI: Confidence Interval, LL: Lower Level, UL: Upper Level, FIQ: Fibromyalji Impact Questionnarie, EMD: Emotional Deprivation, VUL: Vulnerability to Harm, Note: Only significant results are included in the table. 


\section{Discussion and Conclusion}

Our findings supported the hypothesis that there would be an association between fibromyalgia severity and EMS. We found significantly higher scores on emotional deprivation, failure to achieve, dependence /incompetence, vulnerability to harm, enmeshment, subjugation, self-sacrifice, and pessimism /negativity schemas in the group with fibromyalgia. We also found positive correlations with FIQ, emotional deprivation, and vulnerability to harm schemas and negative correlations with subjugation and self-punitiveness schemas. Finally, we found that emotional deprivation and vulnerability to harm schemas predicted FIQ scores even after controlling for age. To the best of our knowledge, this is the second article to examine the effect of EMS on fibromyalgia patients. We discuss the possible implications of our findings below.

Fibromyalgia is a common disease with a complex picture including chronic widespread pain, fatigue, sleep complaints, cognitive difficulties, and somatic symptoms. Fibromyalgia is a disease that progresses with chronic pain. Previous studies have generally focused on chronic pain patients. However, chronic pain can have more than one cause. Fibromyalgia, on the other hand, is the most associated with psychological factors. A recent study showed that in addition to biological characteristics, low endurance and high catastrophizing scores were associated with fibromyalgia complaints (22). Another study reported that fibromyalgia patients had more anxiety and depressive symptoms compared to rheumatoid arthritis and spondyloarthritis patients. Again, in this study, it was reported that maladaptive coping strategies such as high catastrophizing and low ignoring pain were used more (23). In a previous study with fibromyalgia patients, it was reported that fibromyalgia patients scored higher on all schemes, except for insufficient self-control, compared to the control group (24).

In addition, there are important findings related to high harm avoidance, low selfdirectedness, and low self-esteem in fibromyalgia patients (25). There are studies in the literature on the relationship between pain and EMS. In a study conducted with 271 people previously diagnosed with chronic pain, EMS was found to be associated with pain intensity, pain duration, and disability. In the study, unrelenting standards and selfsacrifice schemas were reported as the two most common studies (8). In a planned study compared with the control group, the chronic pain group scored higher on the vulnerability to harm, dependence /incompetence, and pessimism /negativity charts (14). Although they do not include the EMS theory, few studies addressing the relationship between negative childhood experiences and fibromyalgia point to the importance of this relationship $(5,6)$. Therefore, determining psychological factors in fibromyalgia may be important in terms of determining possible intervention targets.

In this study, the mean scores of fibromyalgia patients were found to be higher in 8 schemas compared to the control group. Recent work conceptualizes 18 schemas in 4 domains; Disconnection \& rejection, impaired \& performance, excessive responsibility \& standards, and impaired limits (26). Interestingly, failure to achieve, dependence /incompetence, vulnerability to harm, enmeshment, and subjugation among the schemas that were found to be significant in the patient group; It stands out as 5 out of 6 schemas in the domain of impaired autonomy and performance (26). This area defines the lack of ability of individuals to act individually and to become independent from the environment. Typically, these families are distrustful, intrusive, or overprotective. People who cannot be individualized in life and who are dependent on others for self-realization are likely to present with complaints that have a psychological dimension, such as fibromyalgia. Our findings especially point to the importance of schemas in this area.

The traditional depressive theory of the cognitive model emphasizes the concept of the cognitive triad in depression. People see themselves, the world, and the future as 
pessimistic (27). In particular, pessimism/negativity and failure to achieve schemas may play an important role in fibromyalgia patients with frequent accompanying depressive complaints. Schemas related to pessimism/negativity and failure to achieve are also associated with poor treatment success or can have negative consequences, such as being labeled as 'difficult patient, dissatisfied patient' in the healthcare system.

Subjugation refers to surrendering to the control of others to free themselves from anger, retaliation, or abandonment. People feel that their feelings and thoughts are unimportant to others and may cause anger accumulation and psychosomatic complaints. Enmeshment often involves an overly emotional attachment to important people, such as families, and the belief that without them one cannot properly manage his life. It produces symptoms such as loss of personal boundaries, disappearance in others, or suffocation. Individuals with a dependence/incompetence schema are defined as those who cannot take care of themselves or cope with life on their own (28). In summary, these three schemas point to people's dependence on others and the belief that they are not self-sufficient. People may be calling for support from their environment or health systems under their schema.

Self-sacrifice refers to people's orientation to those around them rather than their own needs. These people often take on the role of a caregiver, which may cause them to hide their aches and pains. Theoretically, schema theory stated that the self-sacrifice schema is common in psychosomatic disorders such as headache, gastrointestinal problems, and chronic pain. The self-sacrifice scheme often accompanies the emotional deprivation scheme (28). In a study conducted with chronic pain patients, it was reported that emotional deprivation in the total sample and self-sacrifice in women predicted pain severity (8). Self-sacrifice individuals are also outward-oriented patients who provide support to their environment at the expense of giving up their own needs. Turning to their own needs may even cause them to feel guilty (29). The intense existence of this schema and the failure to receive the expected response from time to time may cause negative emotions and burnout in the long run.

Our regression analysis results indicate that the emotional deprivation and vulnerability to harm schemas predict FIQ scores. In a recent study, overall higher scores were found on the schemas in somatization disorder, but the vulnerability to harm schema was reported to be related to somatization when depressive symptoms were controlled (16).

Vulnerability to harm beliefs can cause a person to catastrophize their bodily problems and consequences. Catastrophizing pain, fear, and avoidance have an important role in chronic pain (30). Patients with this schema may experience a desperate and exaggerated fear that a disaster will come at any moment. This disaster can be a medical illness, emotional or external problem such as an earthquake. Their parents can typically be expected to be overprotective or uncaring parents (28). Patients with pronounced vulnerability to harm schemas may experience more severe fibromyalgia complaints. At the same time, especially undetected sources of pain may activate patients' beliefs that they will not recover and may activate this schema.

Emotional deprivation is the belief that one's emotional support needs will not be adequately met by others. A lack of attention is conceptualized as a lack of empathy and a lack of protection. One of the strategies for coping with this schema is to constantly focus on the needs of others, thus ignoring their own needs being met. Psychosomatic complaints such as pain, gastrointestinal problems, and fatigue are common in patients with this schema (28). Secondary gains can also serve the emotional deprivation scheme. Patients with a pronounced emotional deprivation schema have less belief that they will receive outside help. This could be another alternative explanation of the pessimism/negativity schemas.

It has been shown that childhood negative experiences can alter neural networks and their function in a developing brain (31). It is accepted that these experiences are associated with fibromyalgia, chronic fatigue syndrome and psychosomatic disorders (32). 
Our findings point to the importance of schemas in patients with fibromyalgia. Fibromyalgia is a disease of unclear etiology and has been associated with psychological factors in many studies. In this sense, this study from the perspective of schema theory draws attention to possible treatment targets.

In summary, patients with a diagnosis of fibromyalgia who applied to a physical therapy and rehabilitation clinic were discussed in this study. The age range typically suits fibromyalgia patients. In the light of the recommendations of previous studies, the control group was also included in this study (8). Among our limitations are that the study was designed as cross-sectional and based on self-report scales. Therefore, studies with larger participants and longitudinal planning may be beneficial. In addition, the role of anxiety and depression symptoms in this relationship should be clarified.

\section{REFERENCES}

1. Wolfe F, Smythe HA, Yunus MB, et al. The American College of Rheumatology 1990 criteria for the classification of fibromyalgia. Arthritis Rheumatol. 1990;33:160-72.

2. Bucourt E, Martaillé V, Mulleman D, et al. Comparison of the Big Five personality traits in fibromyalgia and other rheumatic diseases. Joint Bone Spine. 2017;84:203-7.

3. Kool MB, van de Schoot R, García IL-C, et al. Measurement invariance of the Illness Invalidation Inventory $(3 * I)$ across language, rheumatic disease and gender. Ann Rheum Dis. 2014;73:551-6.

4. Macfarlane GJ, Kronisch C, Dean LE, et al. EULAR revised recommendations for the management of fibromyalgia. Ann Rheum Dis. 2017;76:318-28.

5. Imbierowicz K, Egle UT. Childhood adversities in patients with fibromyalgia and somatoform pain disorder. Eur J Pain. 2003;7:113-9.

6. Walker E, Keegan D, Gardner G, et al. Psychosocial factors in fibromyalgia compared with rheumatoid arthritis: II. Sexual, physical, and emotional abuse and neglect. Psychosom Med. 1997;59:572-7.

7. Schofferman J, Anderson D, Hines R, et al. Childhood psychological trauma and chronic refractory low-back pain. Clin $J$ Pain. 1993;9:260-5.

8. Saariaho TH, Saariaho AS, Karila IA, et al. Early maladaptive schemas in Finnish adult chronic male and female pain patients. Scand J Pain. 2010;1:196-202.
Nevertheless, our findings may be useful as an EMS evaluation in fibromyalgia patients compared to the control group.

\section{Conclusion}

According to our results, many EMS were found to be more severe in fibromyalgia patients compared to the control group. We suggest that early experiences may be important in patients with fibromyalgia, as well as other chronic pain conditions. A multidimensional approach in the treatment of fibromyalgia can contribute to the treatment process. We, therefore, draw attention to the importance of EMS from a schema theory perspective and suggest that they may be a potential target of intervention.

\section{* Presented as an oral presentation at the 28th National Physical Medicine and Rehabilitation Congress with International Participation.}

9. Sansone RA, Pole M, Dakroub H, et al. Childhood trauma, borderline personality symptomatology, and psychophysiological and pain disorders in adulthood. Psychosomatics. 2006;47:158-62.

10. Davis DA, Luecken LJ, Zautra AJ. Are reports of childhood abuse related to the experience of chronic pain in adulthood?: a meta-analytic review of the literature. Clin J Pain. 2005;21:398-405.

11. Young JE. Cognitive therapy for personality disorders: A schema-focused approach Professional Resource Press/Professional Resource Exchange: 1999.

12. Bach B, Bernstein DP. Schema therapy conceptualization of personality functioning and traits in ICD-11 and DSM-5. Curr Opin Psychiatry. 2019;32:38-49.

13. Arntz A, Van Genderen H, Drost J. Schema therapy for borderline personality disorder. Wiley Online Library: 2009.

14. Saariaho TH, Saariaho AS, Karila IA, et al. Early maladaptive schemas in Finnish adult chronic pain patients and a control sample. Scand J Psychol. 2011;52:146-53.

15. Saariaho T, Saariaho A, Karila I, et al. Early maladaptive schema factors, pain intensity, depressiveness and pain disability: An analysis of biopsychosocial models of pain. Disabil Rehabil. 2012;34:1192-201.

16. Henker J, Keller A, Reiss N, et al. Early maladaptive schemas in patients with somatoform disorders and somatization. Clin Psychol Psychother. 2019;26:418-29. 
17. Ribas KHdS, Ribas VR, Barros SSM, et al. The participation of Early Maladaptive Schemas (EMSs) in the perception of pain in patients with migraine: A psychological profile. Dement Neuropsychol. 2018;12:6874.

18. Burckhardt CS, Clark SR, Bennett RM. The fibromyalgia impact questionnaire: development and validation. $J$ rheumatol. 1991;18:728-33.

19. Sarmer S, Ergin S, Yavuzer G. The validity and reliability of the Turkish version of the Fibromyalgia Impact Questionnaire. Rheumatol Int. 2000;20:9-12.

20. Young JE, Brown G. Young Schema Questionnaire-Short Form; Version 3. Psychol Assess. 2005.

21. Soygüt G, Karaosmanoğlu A, Çakir Z. Erken Dönem Uyumsuz Şemaların Değerlendirilmesi: Young Şema Ölçeği Kısa Form-3'ün Psikometrik Özelliklerine İlişkin Bir İnceleme. Turk Psikiyatri Derg. 2009;20.

22. Pulido-Martos M, Luque-Reca O, SeguraJiménez V, et al. Physical and psychological paths toward less severe fibromyalgia: A structural equation model. Ann Phys Rehabil Med. 2020;63:46-52.

23. Bucourt E, Martaillé V, Goupille P, et al. A comparative study of fibromyalgia, rheumatoid arthritis, spondyloarthritis, and Sjögren's syndrome; Impact of the disease on quality of life, psychological adjustment, and use of coping strategies. Pain Med. 2021;22:372-81.

24. Galvez-Sánchez CM, Duschek S, Del Paso GAR. Psychological impact of fibromyalgia: current perspectives. Psychol Res Behav Manag. 2019;12:117.

25. Arıc1, Ö. E., Karaca, B. K., \& Dönmez, B. K. (2021). Fibromiyalji sendromu tanıs1 alan ve almayan hastaların erken dönem uyumsuz şemalar açısından karşılaştırılması. Klinik Psikoloji Dergisi. 2021; 128-144

26. Bach B, Lockwood G, Young JE. A new look at the schema therapy model: organization and role of early maladaptive schemas. Cogn Behav Ther. 2018;47:328-49.

27. Beck JS, Beck AT. Cognitive therapy: Basics and beyond. Guilford press New York: 1995.

28. Young JE, Klosko JS, Weishaar ME. Schema therapy: A practitioner's guide. Guilford Press: 2003.

29. Arntz A, Jacob G. Schema therapy in practice: An introductory guide to the schema mode approach. John Wiley \& Sons: 2017.

30. Vlaeyen JW, Linton SJ. Fear-avoidance and its consequences in chronic musculoskeletal pain: a state of the art. Pain. 2000;85:317-32.

31. Hambrick EP, Brawner TW, Perry BD. Timing of Early-Life Stress and the Development of Brain-Related Capacities. Front Behav Neurosci. 2019;13:183.

32. Roelofs K, Spinhoven P. Trauma and medically unexplained symptoms towards an integration of cognitive and neuro-biological accounts. Clin Psychol Rev. 2007 ;27:798820 .

๑Copyright 2022 by Osmangazi Tıp Dergisi - Available online at tip.ogu.edu.tr @Telif Hakkı 2022 ESOGÜ Tıp Fakültesi - Makale metnine dergipark.org.tr/otd web sayfasından ulaşılabilir. 